\title{
Dried Powders of Velvetbean and Pine Bark Added to Soil Reduce Rhizoctonia solani-Induced Disease on Soybean
}

\author{
Luiz E. B. Blum ${ }^{1 *}$ \& Rodrígo Rodríguez-Kábana ${ }^{2}$ \\ 'Departamento de Fitopatologia, Universidade de Brasília, CEP 70910-900, Brasília, DF, Brazil, \\ e-mail: luizblum@unb.br; ${ }^{2}$ Department of Plant Pathology, Auburn University, 209 Life Sciences Building, 36849 \\ Auburn AL, USA
}

(Aceito para publicação em 19/05/2006)

Author for correspondence: Luiz E.B. Blum

BLUM, L.E.B. \& RODRÍGUEZ-KÁBANA, R. Dried powders of velvetbean and pine bark added to soil reduce Rhizoctonia solani-induced disease on soybean. Fitopatologia Brasileira 31:261-269. 2006.

\begin{abstract}
Diseases induced by Rhizoctonia solani, like damping-off and root and stem rot on soybean (Glycine max), are a serious problem around the world. The addition of some organic material to soil is an alternative control for these diseases. In this study, benzaldehyde and dried powders of kudzu (Pueraria lobata), velvetbean or mucuna (Mucuna deeringiana), and pine bark (Pinus spp.) were used in an attempt to improve soybean plant growth and to reduce the disease $R$. solani (AG-4) causes on soybean. Benzaldehyde $(0.1-0.4 \mathrm{~mL} / \mathrm{kg}$ of soil) and velvetbean $(25-100 \mathrm{~g} / \mathrm{kg})$ significantly $(\mathrm{P} \leq 0.05)$ reduced mycelial growth of $R$. solani in laboratory tests. In greenhouse experiments, the percentage of non-diseased plants was higher in treatments with pine bark and velvetbean $(50-100 \mathrm{~g} / \mathrm{kg})$. In soil treated with kudzu $\left(\mathrm{r}^{2}=0.91\right)$ or velvetbean $\left(\mathrm{r}^{2}=0.94\right)$, increasing rates of these amendments tended to increase plant fresh mass. In microplot field conditions, soil amended with velvetbean $\left(\mathrm{r}^{2}=0.85\right)$ and pine-bark $\left(\mathrm{r}^{2}=0.61\right)$ significantly reduced disease on soybean. Numbers of Bacillus megaterium $\left(\mathrm{r}^{2}=0.87\right)$ and Trichoderma hamatum $\left(\mathrm{r}^{2}=0.92\right)$ and hydrolysis of fluorescein diacetate $\left(\mathrm{r}^{2}=0.91\right)$ were higher in soil amended with increasing rates of velvetbean, indicating an increase in microbial activity. From this study it is concluded that dried powders of velvetbean and pine bark added to soil can reduce Rhizoctonia-induced disease on soybean.
\end{abstract}

Additional keywords: Glycine max, Mucuna deeringiana, damping-off, microbial activity.

\section{RESUMO}

Pós secos de mucuna e casca de pinus adicionados ao solo reduzem a doença causada por Rhizoctonia solani em soja.

As doenças em soja (Glycine max) causadas por Rhizoctonia solani são um sério problema ao redor do mundo. A incorporação ao solo de resíduos orgânicos é uma alternativa para o controle destas doenças. Neste estudo, benzaldeido e pós-secos de kudzu (Pueraria lobata), mucuna (Mucuna deeringiana) e casca de pinus (Pinus spp.) foram usados com o objetivo de melhorar o crescimento de plantas de soja e de diminuir a doença causada por $R$. solani (AG-4). Benzaldehyde $(0,1-0,4 \mathrm{~mL} / \mathrm{kg}$ de solo) e mucuna $(25-100 \mathrm{~g} / \mathrm{kg})$ reduziram significativamente $(\mathrm{P} \leq 0.05)$ o crescimento micelial de $R$. solani em experimentos de laboratório. Em experimentos conduzidos em casa de vegetação a porcentagem de plantas sobreviventes foi maior em solo com casca de pinus e mucuna $(50-100 \mathrm{~g} / \mathrm{kg})$. Em solo tratado com kudzu $\left(\mathrm{r}^{2}=0,91\right)$ ou mucuna $\left(r^{2}=0,94\right)$, houve tendência significativa em aumentar a massa fresca das plantas de soja. Em microparcelas de campo solos com mucuna $\left(r^{2}=0,85\right)$ ou com casca de pinus $\left(r^{2}=0,61\right)$ reduziram significativamente a quantidade de doença. A quantidade de Bacillus megaterium $\left(\mathrm{r}^{2}=0,87\right)$ e Trichoderma hamatum $\left(\mathrm{r}^{2}=0,92\right)$ e a hidrólise de diacetato fluoresceina $\left(\mathrm{r}^{2}=0,91\right)$ foram maiores em solo com doses crescentes de mucuna, indicando uma maior atividade microbiana. Neste estudo conclui-se que pós-secos de mucuna e casca de pinus, incorporados ao solo, podem reduzir a doença causada por $R$. solani em soja.

Palavras-chave adicionais: Glycine max, Mucuna deeringiana, tombamento, atividade microbiana.

\section{INTRODUCTION}

Rhizoctonia solani J.G. Kühn [teleomorph Thanatephorus cucumeris (A.B. Frank) Donk] is one important cosmopolitan necrotrophic soil-borne fungus. This fungus occurs from temperate to tropical climates

*CNPq Fellowship. causing seed and fruit decay, damping-off, root rots, stem cankers, and leaf diseases in many crop plants. It can survive in soil by colonizing plant debris and roots of weed hosts, and through production of sclerotia (Adams, 1988).

Diseases caused by $R$. solani cause yield losses in more than 200 crops throughout the world (Windels et al., 1997). In soybean [Glycine max (L.) Merr.] in the USA, R. solani is one of the principal causes of seed and seedling damping- 
off (McGee, 1992). Tachibana et al. (1971) reported yield losses on soybean as high as $60 \%$ under field conditions in Iowa. Two decades later, Rizvi \& Yang (1996) found that the amount of $R$. solani isolated from soybean seedlings ranged from 14 to $44 \%$. Control of disease caused by R. solani has been attempted by various methods including: fungicides, antagonists, crop rotation, solarization, and resistant cultivars (Kataria \& Grover, 1987; Lewis \& Papavizas, 1987; Verma, 1996; Voland \& Epstein, 1994).

Biocontrol of phytopathogens involves the use of biological processes to reduce pathogen populations to levels below disease threshold. The aim is to reduce crop losses and interfere minimally with an ecosystem. Organic matter added to soil naturally or intentionally may increase soil fertility and growth of subsequent crops and inhibit plant pathogens (Linderman, 1989). Organic amendments to soil may diminish or intensify diseases (Gamliel \& Stapleton, 1993; Kataria \& Grover, 1987). The use of organic amendments to soil is an alternative to reduce disease caused by soilborne pathogens, including $R$. solani (Kokalis-Burelle \& Rodríguez-Kábana, 1994b). This method of disease control work by improving soil structure (texture, drainage, and $\mathrm{pH}$ ) and plant growth (height and weight), by increasing soil microbial buffering capacity, by stimulating indigenous antagonists, and by liberation of pathogen-toxic compounds (Linderman, 1989).

Many plants can be used as soil amendments against $R$. solani, including velvetbean or mucuna [Mucuna deeringiana (Bort) Merr.)] and kudzu [Pueraria lobata (Willd.) Ohwi], both Asian leguminous plants used as green manure and pasture crops. These plants have control activity against insects, nematodes and other soil-borne pathogens when used in crop rotations or when incorporated into soil as green manure. Mucuna induced changes in the rhizosphere microflora of soils cultivated with it, and these changes may have had a suppressive effect on nematodes (Kloepper et al., 1992; Rodríguez-Kábana et al., 1992).

Naturally occurring aromatic compounds offer another option as soil amendments. Benzaldehyde, an oil from bitter almond (Prunus amygdalus Batsch) is a volatile compound used in low concentrations to induce spore germination of fungi and stimulate the activity of selected biological control microorganisms against soil pathogens (Soler-Serratosa, et al. 1996). Additionally, benzaldehyde can be used at higher rates as a fungicidal or fungistatic substance (Wilson et al., 1987).

There is in the literature sufficient evidence indicating that organic amendments can be useful for control of $R$. solani and other soil-borne plant pathogens (Blum \& Rodriguez-Kábana, 2004). Information available also indicates that conditions for success in the use of organic amendments for control of plant pathogens demand precise knowledge on their characteristics, mode of action, and usage methodology. Kudzu, velvetbean, pine bark powder and benzaldehyde are materials available in Alabama which could be used to control $R$. solani if conditions for their application were known.

The main objectives of this study were to evaluate the effect of different rates of kudzu, velvetbean, pine bark powder, and benzaldehyde on growth of $R$. solani under controlled laboratory conditions, on soybean damping-off and stem rot under greenhouse and field conditions, and on soil microbial population and activity.

\section{MATERIAL AND METHODS}

Inoculum production - Rhizoctonia solani (AG-4) was isolated from soybean ('Davis') seedlings showing root and stem rot. This isolate was maintained $\left(10-15{ }^{\circ} \mathrm{C}\right)$ in test tubes with MEA (Malt extract agar - Difco Co.) or PDA (Potato dextrose agar - Difco Co.). Production of inoculum of $R$. solani for studies on mycelial growth or soil infestation followed methods similar to those for production of Sclerotium rolfsii Sacc. inoculum in sterile oat (Avena sativa L.) seeds (Carling \& Sumner, 1992). R. solani was grown on oat seeds for three weeks, dried $\left(20-25^{\circ} \mathrm{C}\right)$ for one week, and maintained $\left(10-15^{\circ} \mathrm{C}\right)$ in closed plastic boxes.

Soil characteristics - Soil used for laboratory and greenhouse experiments was a sieved $(2 \mathrm{~mm})$ sandy-loam-soil, mixed with river sand $(50: 50 \mathrm{w} / \mathrm{w})$. The elemental composition and other characteristics of soils used in the experiments is the following: (a) Laboratory / Greenhouse soil - Source area, Auburn, AL; Previous crop, Peanut (Arachis hypogaea L.); Type, sandy loam; CEC <4.6 cmol/kg; pH 6.8; P $19.5 \mathrm{mg} /$ kg; k 38 mg/kg; Mg 65 mg/kg; Ca 300 mg/kg; N 0.04\%; (b) Microplot Field soil - Source area, Elberta, AL; Previous crop, Cotton (Gossypium hirsutum L.); Type, sandy loam; $\mathrm{CEC}<4.6 \mathrm{cmol} / \mathrm{kg} ; \mathrm{pH} 6.2 ; \mathrm{P} 44.5 \mathrm{mg} / \mathrm{kg}$; $\mathrm{K} 22.5 \mathrm{mg} / \mathrm{kg}$; $\mathrm{Mg} 28.5 \mathrm{mg} / \mathrm{kg}$; Ca $375 \mathrm{mg} / \mathrm{kg}$; N 0.05\%.

Amendments - Commercially available pine bark nuggets (Pinus elliottii Engelm. and P. taeda L.) (ProCare Earth Pak Ink., Madison, GA, USA) and locally collected three-monthold (pre-reproductive stage) kudzu and mucuna plants (leaves and stems) were used as amendment in the experiments. These materials were dried for two weeks on greenhouse benches $\left(25-32{ }^{\circ} \mathrm{C}\right)$, ground $(<500 \mu \mathrm{m})$ in a Straub Model 4E Grinding Mill (Straub Co., Philadelphia, PA, USA), and then stored in plastic boxes at room temperature $\left(20-25^{\circ} \mathrm{C}\right)$. The Soil Testing Laboratory at Auburn University (Auburn, $\mathrm{AL})$ determined the elemental composition of the materials (Table 1).

Laboratory experiments - Two laboratory experiments were performed to evaluate the immediate effect of amendments on mycelial growth of $R$. solani on the soil surface. For both experiments, the treatments were: non-amended soil (control), benzaldehyde (0.1, 0.2, and $\left.0.4 \mathrm{~mL} . \mathrm{Kg}^{-1}\right)$, kudzu powder $(25,50$, and $100 \mathrm{~g} / \mathrm{kg})$, mucuna powder $(25,50$, and $100 \mathrm{~g} / \mathrm{kg})$, pine bark powder $(25,50$, and $100 \mathrm{~g} / \mathrm{kg})$, and a control with sterile soil (autoclaved). Each treatment was 
Dried powders of velvetbean and pine bark added to soil...

TABLE 1 - Elemental composition of ground dry kudzu (Pueraria lobata), velevetbean (Mucuna deeringiana) and pine bark (Pinus spp.)

\begin{tabular}{|c|c|c|c|c|c|c|c|c|c|c|c|}
\hline \multirow{2}{*}{ Amendment } & \multirow{2}{*}{$\mathrm{C}: \mathrm{N}^{*}$} & $C^{* *}$ & $\mathbf{N}$ & $\mathbf{P}$ & $\mathbf{K}$ & Mg & $\mathrm{Fe}$ & Mn & Zn & B & $\mathbf{N a}$ \\
\hline & & \multicolumn{5}{|c|}{$\%$} & \multicolumn{5}{|c|}{$\mathrm{mg} / \mathrm{kg}$} \\
\hline Kudzu $* * *$ & 32.1 & 44.3 & 1.4 & 0.1 & 0.8 & 0.3 & 308.5 & 49.5 & 11.3 & 24.2 & 97.4 \\
\hline Velvetbean $* * *$ & 17.3 & 45.0 & 2.6 & 0.3 & 1.6 & 0.4 & 498.4 & 219.4 & 20.4 & 30.0 & 185.1 \\
\hline Pine bark & 235.3 & 51.8 & 0.2 & $<0.1$ & 0.1 & $<0.1$ & 94.9 & 73.4 & 12.6 & 7.4 & 7.2 \\
\hline
\end{tabular}

\footnotetext{
*Carbon: Nitrogen ratio;

**Analyses made by Auburn University, Soil Testing Laboratory, Auburn, AL, USA.

***Three-month-old plants (pre-reproductive phase).
}

replicated five times. An experimental unit was a $150 \mathrm{~mL}-$ plastic cup with $100 \mathrm{~g}$ of soil.

Applications were made by mixing soil with the amendments in small polyethylene plastic bags $(15 \times 15$ $\mathrm{cm})$. The resulting mixture was transferred to plastic cups and $20 \mathrm{~mL}$ of sterile water was added to each cup and thoroughly mixed again. Five $R$. solani colonized oat seeds were put on soil surface, each set $1.5 \mathrm{~cm}$ apart in cross design. This method is a modification of Rodríguez-Kábana et al. (1975) method's for screening of pesticides against S. rolfsii (Blum \& Rodríguez-Kábana, 2004). Cups were then closed with a plastic lid with a small hole on it $(2 \mathrm{~mm})$, to allow gas exchange, and incubated at $27{ }^{\circ} \mathrm{C}$ (Precision Scientific incubator - GCA Corporation, USA). Cups with benzaldehyde-treated soil were placed in plastic boxes with cover lids to avoid contamination of other treatments with benzaldehyde vapor. Superficial mycelial growth was evaluated for each seed of each replication every $24 \mathrm{~h}$ after soil incubation, for 10 days, under stereoscopic microscope (10X), following a subjective superficial mycelial growth index $(1 \leq 1 \mathrm{~mm}$ growth from the inoculum seed; $2=1-3$ $\mathrm{mm} ; 3 \geq 3 \mathrm{~mm})$.

\section{Greenhouse experiments - Effects on soybean survival}

Two experiments were performed under greenhouse conditions to evaluate the efficacy of benzaldehyde $(0.1$, 0.2 , and $0.4 \mathrm{~mL} . \mathrm{Kg}^{-1}$ of soil), kudzu, mucuna, and pine bark powder $(25,50$, and $100 \mathrm{~g} / \mathrm{kg})$ on 'Davis' soybean survival in soil infested with $R$. solani. Controls with sterilized and natural soils, with and without pathogen were included. The experiments were arranged in a randomized complete design, with 16 treatments and five replications. An experimental unit consisted of a pot (1 1 capacity 10 -cm-diameter cylindrical PVC pot) with $1 \mathrm{~kg}$ of soil.

For both experiments, a day before application of the amendments, $5 \mathrm{~g}$ of $R$. solani colonized oat seeds were added to $1 \mathrm{~kg}$ of soil. For soil infestation and application of the amendments each replication was thoroughly mixed in polyethylene plastic bags. Ten 'Davis' soybean seeds were sown in each pot 21 days after application of the amendments. The number of surviving and diseased plants was evaluated 21 days after sowing.
Effects on survival and growth of soybean and on soil enzymatic activity - Four more greenhouse experiments were performed to evaluate the effect of different rates of amendments on 'Young' soybean plant survival and growth, soil enzymatic activity, and disease incidence. Four rates of kudzu, mucuna, and pine bark powder $(0,5,10,20$, and 30 $\mathrm{g} / \mathrm{kg}$ ), and four of belzaldehyde $(0.0,0.2,0.4,0.8$, and 1.2 $\left.\mathrm{mL} . \mathrm{Kg}^{-1}\right)$ were applied. Treatments were replicated six times and arranged in a randomized complete block design. Each experimental unit consisted of a pot (1 1 capacity cylinder shape PVC pot) with $1 \mathrm{~kg}$ of soil.

Infestation was effected seven days before application of the amendments with $5 \mathrm{~g} / \mathrm{kg}$ of $R$. solani colonized oat seeds. Five soybean seeds / pot were sown 30 days after application of the amendments. For soil infestation and application of the amendments, all replications were thoroughly mixed in polyethylene plastic bags $(30 \times 20$ $\mathrm{cm})$. Evaluations of germination were performed seven days after sowing. Sixty days after sowing, measurements of plant height and fresh weight, and number of surviving and diseased plants were recorded.

Thirty days after application of the amendments, soil samples were collected, dried $\left(20-25^{\circ} \mathrm{C}\right)$ for one week, and stored at $4{ }^{\circ} \mathrm{C}$, for evaluation of the esterase activity (hydrolysis of fluorescein diacetate). The method used to measure esterase activity was a modification of the method described by Schnürer \& Rosswall (1982). Precisely $2 \mathrm{~kg}$ of soil, were placed in $30 \mathrm{~mL}$ plastic cups. Ten $\mathrm{mL}$ of sterile phosphate buffer $(60 \mathrm{mM}, \mathrm{pH} 7.55)$ were added, followed by $1 \mathrm{~mL}$ of a solution of fluorescein diacetate (Aldrich Chemical) dissolved in acetone $(1 \mathrm{mg} / \mathrm{mL}$ ) (acetone certified A.C.S. Fisher Chemical). All cups were mixed gently, covered, and incubated for 30 minutes at $28{ }^{\circ} \mathrm{C}$ (Precision Scientific incubator).

Following to incubation, $10 \mathrm{~mL}$ of acetone were added to the cups to stop the reaction. Ten $\mathrm{mL}$ of the resulting suspension were centrifuged for 10 minutes at 3000 rpm (Centrifuge Model HN, International Equipment Co., USA). Optical density (OD) at $490 \mathrm{~nm}$ of the supernatant was determined with a Spectronic 601 (Milton Roy Co., Analytical Products Division, USA). Readings were 
expressed in terms of $\mu \mathrm{g}$ of fluorescein released per hour per $\mathrm{g}$ of soil $\left(\mu \mathrm{g}\right.$ of fluorescein $\left.\mathrm{h}^{-1} \mathrm{~g}^{-1}\right)$. Calibration curve with Fluorescein Na salt (Aldrich Chemical, USA), was prepared to convert OD readings into $\mu \mathrm{g}$ of fluorescein. Controls with $\left(121^{\circ} \mathrm{C}, 15\right.$ minutes) and without sterile soil were included to account for background readings.

Field experiments - Amendments with the best efficacy against $R$. solani were chosen for further evaluation in a microplot field experiment. In the experiment, mucuna and pine bark powders were applied at rates of: $0,5,10,15,20$, and $25 \mathrm{~g} / \mathrm{kg}$ of soil, and benzaldehyde at $0,0.1,0.2,0.4,0.6$, and $0.8 \mathrm{~mL} / \mathrm{kg}$ of soil. For these materials two controls were included without pathogen: one without any amendment and other with the highest rate of the amendment. Treatments were arranged in a randomized complete block design with eight treatments and four replications. Two days prior application of the amendments, $5 \mathrm{~kg}$ of soil / replication were infested with $R$. solani colonized oat seeds at a rate of $5 \mathrm{~g} / \mathrm{kg}$ of soil. Twenty-one days after application of the amendments, each microplot $(30 \times 30 \times 60 \mathrm{~cm})$ was sown with 20 'Young' soybeans evenly spaced $(5 \times 5 \mathrm{~cm}$ and $2 \mathrm{~cm}$ deep). For soil infestation and application of the amendments, $5 \mathrm{~kg}$ of soil of each replication were thoroughly mixed in $10 \mathrm{~L}$ plastic pots. Watering of microplots was by drip irrigation and as needed.

Fourteen days after sowing (d.a.s.) the total number of plants and the number of diseased (damping-off and stem rot) plants were recorded. Sixty d.a.s., from each microplot, the fresh mass of above ground parts of plants was determined.

Evaluation of microbial population - Sixty days after soil amendment, numbers of fungi and bacteria were evaluated by traditional soil serial dilution method. Ten grams of freshly collected soil from each plot were thoroughly mixed for $5 \mathrm{~min}$ (45 x 30-cm tray shaker, Arthur H. Thomas Co., USA) with 90 $\mathrm{mL}$ of sterile water in $150 \mathrm{~mL}$ capacFor fungi, dilutions $10^{-2}$ and $10^{-3}$ were used and for bacteria $10^{-5}$ and $10^{-6}$. The resulting suspensions were then spiral plated (Spiral System Instruments, USA) in the appropriate culture media.

The selective medium used to isolate fungi from soil was MEA (Difco) amended with $100 \mathrm{mg} / \mathrm{l}$ of tetracycline hydrochloride (Fisher Chemical, USA), and $50 \mathrm{mg} / \mathrm{L}$ of rose bengal (Fisher Chemical). Isolations of bacteria were done in $5 \%$ TSA (Difco) amended with $50 \mathrm{mg} / \mathrm{L}$ of benomyl (Benlate $50 \mathrm{WP} 100 \mathrm{mg} / \mathrm{L}$ ). Number of colonies per plate was determined directly two and five days after inoculation for bacteria and fungi, respectively.

Twenty bacterial isolates from each replication were randomly picked with sterile tooth picks, grown in TSA, and maintained in small plastic tubes $(1.2 \mathrm{~mL})$ with $1.0 \mathrm{~mL}$ of sterile water. Isolates (1560) from sampling time of the microplot experiment were processed for identification. Identification of bacterial isolates was based on analysis of fatty acid methyl-esters profiles. Bacterial samples were prepared as described by Kloepper et al. (1992), analyzed with a Hewlett-Packard Gas Chromatography Model 5890 Series II (Avondale, USA) with a HP-Ultra 2 diphenil dimethyl siloxane column $(25 \mathrm{~mm}$ length $\mathrm{x} 0.33$ $\mu \mathrm{m}$ thickness $\mathrm{x} 0.2 \mu \mathrm{m}$ inner diameter) and a flame ionizing detector. Identification was according to Sherlock Microbial Identification System (MIDI, Inc., USA) software.

Ten fungal isolates from each replication of the microplot experiment were randomly picked and maintained in tubes with MEA $\left(20-25{ }^{\circ} \mathrm{C}\right)$ for later identification. Identification of isolates was based on morphology and growth on MEA and PDA, and consulting appropriate literature (Domsch et al., 1980).

Statistical analysis - Experiments were arranged in a randomized complete block design, with four or six replications, for field or for greenhouse experiments, respectively. The data were analyzed by two-way ANOVA and differences among treatment means were evaluated for significance using Fisher's Protected LSD test $(\mathrm{P} \leq$ $0.05)$. Correlation and regression analyses were performed when necessary following standard procedures. Statistical analyses were performed using two software programs: SigmaStat v.2 (SPSS / Jandel Scientific Software, USA) and StatView v.4.53 (Abacus Concepts, USA).

\section{RESULTS}

Laboratory experiments - Mycelial growth - All three benzaldehyde rates inhibited superficial mycelial growth of $R$. solani when compared to the non-amended soil $(\mathrm{P} \leq 0.05)$, in both experiments (Figure 1A). After 48h, only the lowest rate of benzaldehyde evidenced some mycelial growth (Figure 1B). Mycelial growth on soil with the highest rates of benzaldehyde ( 0.2 and $\left.0.4 \mathrm{~mL} . \mathrm{Kg}^{-1}\right)$ was observed only after 10 days of incubation (data not shown).

Velvetbean treatments decreased mycelial growth significantly $(\mathrm{P} \leq 0.05)$ after 24 and $48 \mathrm{~h}$ of incubation when compared to the non-treated natural soil (Figure 1A-D). Three days after incubation, no difference was detected among velvetbean treatments and non-treated control (data not shown). Treatments with kudzu and pine bark (50 and $100 \mathrm{~g} / \mathrm{kg}$ ) slightly decreased mycelial growth after $24 \mathrm{~h}$ of incubation and no statistical differences were detected after $48 \mathrm{~h}$, when these treatments were compared to the nontreated soil (Figure 1A - D).

Greenhouse experiments - The most effective treatments in terms of number of soybean plants were: velvetbean 25 $\mathrm{g} / \mathrm{kg}$ in experiment 1 (Figure 1E), velvetbean 50 and 100 $\mathrm{g} / \mathrm{kg}$ in experiment 2 (Figure $1 \mathrm{~F}$ ), and pine bark 50 and 100 $\mathrm{g} / \mathrm{kg}$ in both experiments (Figure $1 \mathrm{E}-\mathrm{F}$ ). The amendments tested added to soil improved $(\mathrm{P} \leq 0.05)$ soybean fresh mass and percentage of surviving plants (Figure 2A - D). The percentage of diseased plants tended to reduce significantly only by addition to soil of velvetbean $\left(\mathrm{r}^{2}=0.97\right)$ and pine bark $\left(r^{2}=0.90\right)$ (Figure 3A - B). For benzaldehyde treatments 

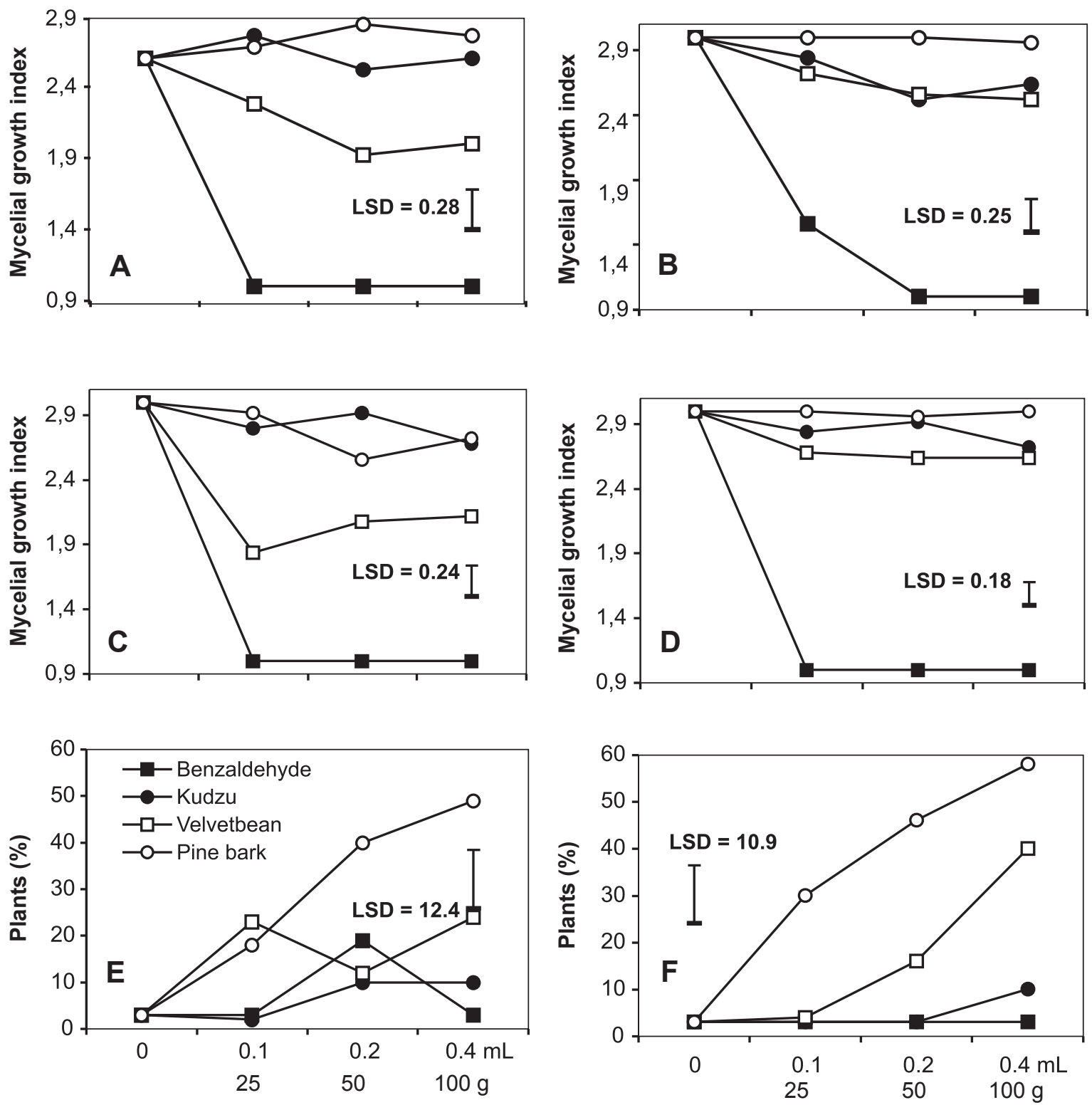

Benzaldehyde (mL.kg-1); Kudzu, Velvetbean and Pine bark (g/kg)

FIG. 1 - (A-D) Effect of amounts of amendments ( $\mathrm{mL} \cdot \mathrm{kg}^{-1}$ for benzaldehyde and $\mathrm{g} \cdot \mathrm{kg}^{-1}$ for kudzu, velvetbean or pine bark) on mycelial growth of Rhizoctonia solani from oat seed inoculum, $24 \mathrm{~h}$; (A and $\mathbf{C}$ represent two laboratory experiments named 1 and 2, respectively) and 48 h; (B and $\mathbf{D}$ represent two laboratory experiments named 1 and 2, respectively) after incubation (Average of five replications with five colonized seeds each; Index for mycelial growth: $1=0-<1 \mathrm{~mm} ; 2=1-3$ $\mathrm{mm} ; 3=>3 \mathrm{~mm})$; (E-F) Percentage of survived plants of soybean cv. 'Davis' 21 days after sowing in infested soil (E and F represent greenhouse experiments 1 and 2, respectively). Bar $=\mathrm{LSD}=$ Fisher's least significant difference $(\mathrm{P}=5 \%)$.

there was negative correlation between esterase activity and rate of amendment $(\mathrm{r}=-0.27)$, and esterase activity and plant fresh mass $(r=0.80)$. Positive correlation was established by the contrasts made with velvetbean and kudzu treatment variables. Treatments with pine bark presented positive correlation between esterase activity and amount of pine bark (Table 2 ).

Microplot experiments - Velvetbean improved $(\mathrm{P} \leq 0.05)$ plant fresh mass $\left(r^{2}=0.90\right)$, percentage $\left(r^{2}=0.77\right)$ of plants
(Figure 2E - F), and decreased the amount of diseased $\left(\mathrm{r}^{2}=0.85\right)$ plants (Figure 3C). Pine bark treatments in did not improve plant fresh mass (Figure $2 \mathrm{~F}$ ), however, decreased the percentage $\left(r^{2}=0.61\right)$ of diseased plants (Figure 3C).

Microbial evaluations - Bacillus megaterium de Bary and T. hamatum (Bonord.) Bainier were most abundant in plots with velvetbean and in those with pine bark amended soil (Figure 3D - E). The frequency of isolation of these microorganisms positively $\left[\mathrm{r}^{2}(B\right.$. megaterium $)=0.87 ; \mathrm{r}^{2}(T$. 

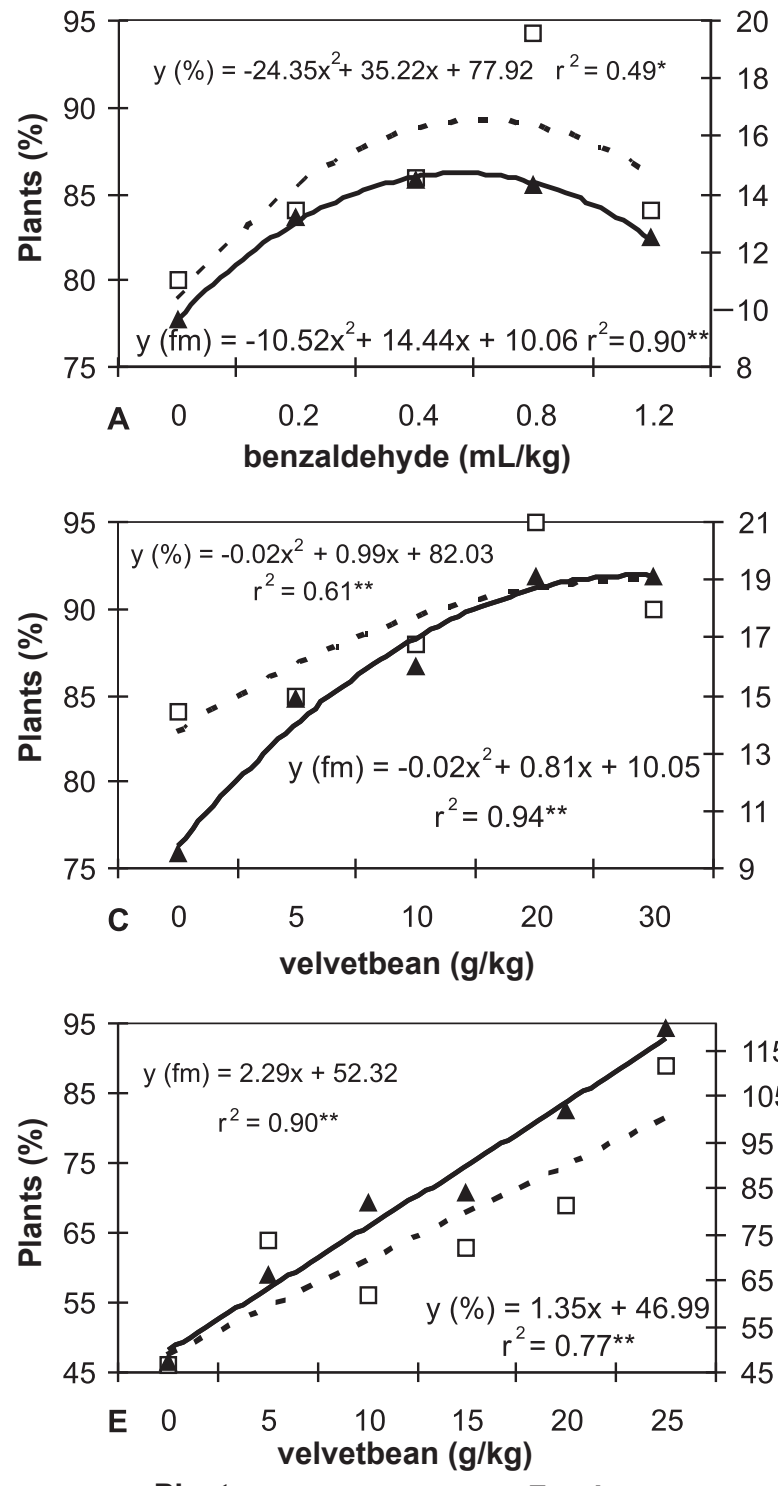

$\square$ Plants
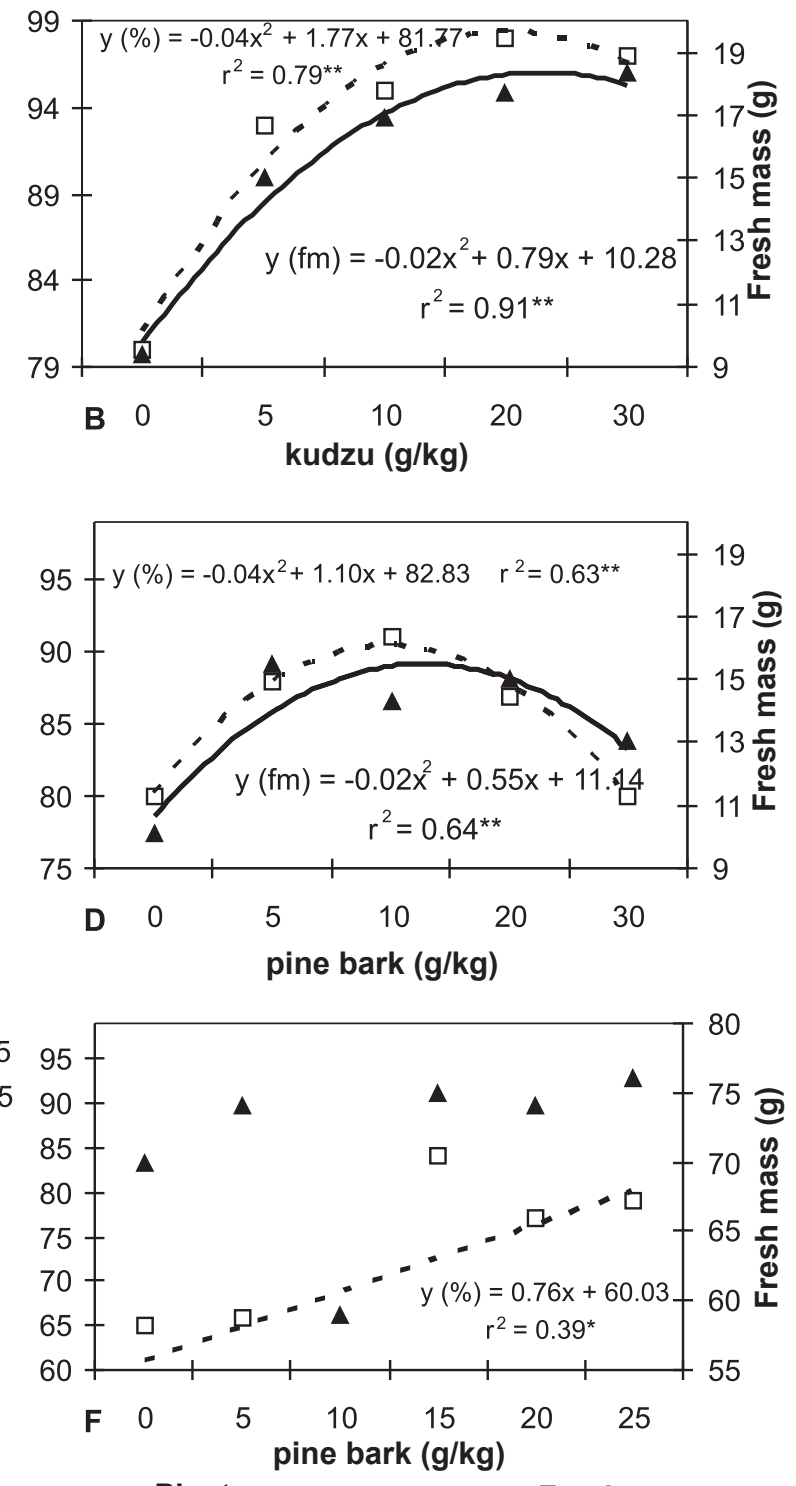

$\square$ Plants

FIG. 2 - Effect of amounts of amendments (benzaldehyde, kudzu, velvetbean, and pine bark) on the percentage (\%, square signal and continuous line) and fresh mass (fm, triangle signal and doted line) of plants per plot, 60 days after sowing ('Davis soybean) in soil infested with Rhizoctonia solani. (A-D) Data collected from greenhouse experiments. (E-F) Data collected from microplot experiments. Regression equation curves with $\mathrm{r}^{2}$ followed by $*$ and $* *$ are statistically significant under $5 \%$ and $1 \%$ of probability, respectively. (F) There was no statistical significance for regression equation involving pine bark.

hamatum $)=0.92]$ increased with the increasing amounts of velvetbean (Figure 3D - E). There was no significant correlation between amount of pine bark and the frequency of isolation of T. hamatum (Figure $3 \mathrm{E}$ ). No significant correlations were observed between amount of amendment and microorganisms in soil with kudzu and benzaldehyde (data not shown).

\section{DISCUSSION}

Kokalis-Burelle \& Rodríguez-Kábana (1994a) studied the effect of pine bark extracts on mycelial growth of $R$. solani in vitro. They observed a reduction on $R$. solani mycelial growth when alkali-extracted compounds from pine bark were added to culture media. Also, they found populations of potential antagonists, such as Penicillium spp., increased in soil in response to pine bark applications. It suggests that not only direct toxic effect of pine bark is involved on the pathogen suppression but also microbial antagonists. In our experiments $R$. solani mycelial growth was reduced $(\mathrm{P} \leq 0.05)$ for $24 \mathrm{~h}$ in treatments with 50 and $100 \mathrm{~g} / \mathrm{kg}$ of pine bark. Benzaldehyde (0.1 to $\left.0.4 \mathrm{~mL} . \mathrm{Kg}^{-1}\right)$, kudzu $(100 \mathrm{~g} / \mathrm{kg})$ and velvetbean $(50$ and $100 \mathrm{~g} / \mathrm{kg})$ reduced fungal mycelial growth for 24 to $48 \mathrm{~h}$. This was probably due to some direct effect of toxic substances liberated by 

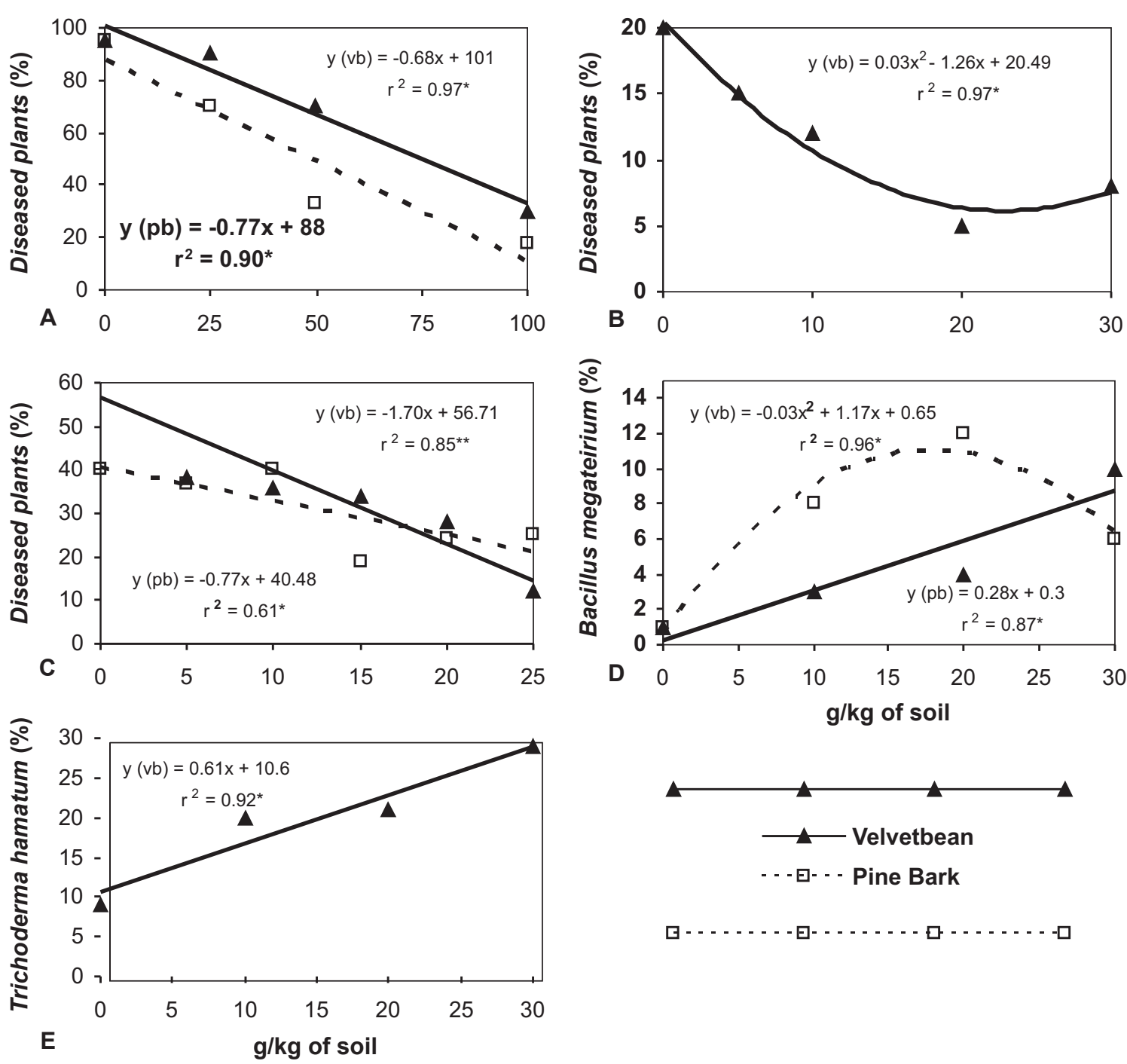

FIG. 3 - Effect of velvetbean (vb) and pine bark (pb) on the percentage of diseased plants per plot, 21 (greenhouse) and 60 (microplot) days after sowing in soil infested with Rhizoctonia solani. (A-B) Data collected from greenhouse experiments. (C-E) Data collected from microplot experiments. Regression equation curves with $\mathrm{r}^{2}$ followed by $*$ and $* *$ are statistically significant under $5 \%$ and $1 \%$ of probability, respectively. (B and $\mathbf{E}$ ) There was no statistical significance for regression equations involving pine bark.

these amendments (kudzu and velvetbean) in soil. This suggests that immediate and short-term effects of some amendments have a role on pathogen and consequently disease suppression.

Benzaldehyde applications resulted in short-term inhibition of $R$. solani growth, however this was not reflected in increased plant stands or in decreases in plant disease incidence. Probably, after a short period of inhibition, the fungistatic action of benzaldehyde stopped and $R$. solani started to grow again and infect seeds and seedlings. Fungistatic effects of benzaldehyde have been noticed before (Caccioni et al., 1995).

Amendments with pine bark under greenhouse and velvetbean under field conditions showed potential to reduce disease and improve plant stand in soil infested with $R$. solani. Kudzu amendments were variable in results in the greenhouse experiments and were not therefore tested in the field. These results suggest that the mechanisms involved in disease suppression with all these amendments are different. Velvetbean initially reduced fungal mycelial (fungistatic effect) growth and increased soil enzymatic activity $30 \mathrm{~d}$ after application of the amendments, indicating high microbial activity in soil (Blum \& Rodríguez-Kábana, 2004; KokalisBurelle \& Rodríguez-Kábana, 1994a; Soler-Serratosa et al., 1996). Amendments with kudzu and pine bark were initially not very suppressive to mycelial growth and resulted in lower enzymatic activity compared to the activity with velvetbean amendments. This might explain why reduction in disease by kudzu and pine bark amendments was less evident than that with velvetbean. 
TABLE 2 - Correlation matrix among soil esterase activity [hydrolysis of fluorescein diacetate ( $\mu \mathrm{g}$ of fluorescein $\left.\mathrm{h}^{-1} \mathrm{~g}^{-1}\right)$ ] and rates $(\mathrm{g}$ or $\mathrm{mL} / \mathrm{kg})$ of amendments and fresh mass $(\mathrm{g})$ of plants per plot, in soil infested with Rhizoctonia solani under greenhouse conditions

\begin{tabular}{lcccc}
\hline \hline \multirow{2}{*}{ Comparison } & \multicolumn{4}{c}{ Amendment } \\
\cline { 2 - 5 } & Benzaldehyde & Kudzu & Velvetbean Pine bark \\
\hline Esterase $x$ rate & $-0.27^{*}$ & $0.87^{* *}$ & $0.91^{* *}$ & $0.70^{* *}$ \\
Esterase $\mathbf{x}$ fresh mass & $-0.80^{* *}$ & $0.56^{* *}$ & $0.77^{* *}$ & n.s. \\
\hline
\end{tabular}

n.s. $=$ no statistical significance.

*statistically significant under $5 \%$ of probability.

**statistically significant under $1 \%$ of probability.

Stimulation in populations of antagonistic microorganisms by the addition of organic matter to soil has been reported before (Kokalis-Burelle \& RodríguezKábana, 1994b). Frequently, species of Trichoderma, like T. hamatum and others, Gliocladium, and Bacillus are associated with parasitism on $R$. solani in suppressive soils (Bertagnolli et al., 1996; Lewis \& Papavizas, 1987; Naiki \& Ui, 1975). Growth-promoting rhizobacteria (Azospirillum, Azotobacter, Bacillus, Clostridium, and Pseudomonas fluorescens-putida Migula) may induce energy stress on R. solani (Gupta et al., 1995), through liberation of carbon compounds from rhizobacteria-colonized sclerotia. Direct effects of amendments, antagonists, and other factors such as soil temperature, moisture, $\mathrm{pH}$, texture, and salt concentration, are also associated with the success or failure of amendments in suppressing diseases (Carling \& Leiner, 1990; Kataria \& Grover, 1987; Kousik et al., 1995; Ogle et al., 1995).

The amounts $(>15 \mathrm{~g} / \mathrm{kg}$ ) of amendments that suppressed $R$. solani and its disease are too high to be used practically under field conditions. However, they are useful for small plots, seedbeds, and greenhouse pots. For extensive field conditions, velvetbean for example, could be grown and incorporated into soil for two consecutive cycles. This could give approximately 12-18 tons/ha of dried matter (Buckles, 1995), amounts that could reduce disease incidence and provide nitrogen for succeeding crops. In Headland, AL, USA, Rodríguez-Kábana et al. (1992) reported that when two cycles of velvetbean (mucuna) preceded peanut there were decreasing in populations of nematodes [Meloidogyne arenaria (Neal) Chitwood] and increasing peanut yield.

In conclusion, velvetbean and pine bark have potential to reduce $R$. solani-induced disease on soybean. Velvetbean also may improve plant fresh mass. These amendments might increase antagonistic microbial activity in soil, a mechanism that possibly is involved on pathogen and disease suppression.

\section{BIBLIOGRAPHIC REFERENCES}

ADAMS, G.C. Jr. Thanatephorus cucumeris (Rhizoctonia solani), a species complex of wide host range. In: Sidhu, G.S. (Ed.)
Advances in plant pathology. Vol. 6: Genetics of plant pathogenic fungi. London. Academic Press. 1988. pp. 535-552.

BERTAGNOLLI, B.L., DAL SOGLIO, F.K. \& SINCLAIR, J.B. Extracellular enzyme profiles of the fungal pathogen Rhizoctonia solani isolate 2B-12 and other two antagonists, Bacillus megaterium starin B153-2-2 and Trichoderma harzianum isolate Th008. I. Possible correlations inhibition of growth and biocontrol. Physiological and Molecular Plant Pathology 48:145-160. 1996.

BLUM, L.E.B. \& RODRÍGUEZ-KÁBANA, R. Effect of organic amendments on sclerotial germination, mycelial growth, and Sclerotium rolfsii-induced diseases. Fitopatologia Brasileira 29:6674. 2004.

BUCKLES, D. Velvetbean: a "new" plant with a history. Economic Botany 49:13-25. 1995.

CACCIONI, D.R.L., TONINI, G. \& GUIZZARDI, M. Antifungal activity of stone fruit aromatic compounds against Monilinia taxa (Aderh. et Ruhl.) Honey and Rhizopus stolonifer (Ehrenb.): in vivo trials. Zeitschrift Pflanzenkrankheiten Pflanzenschutz 102:518525. 1995.

CARLING, D.E. \& LEINER, R.H. Effect of temperature on virulence of Rhizoctonia solani and other Rhizoctonia on potato. Phytopathology 80:930-934. 1990.

CARLING, D.E. \& SUMNER, D.R. Rhizoctonia spp. In: Singleton, L.L., Mihail, J.D. \& Rush, C.M. (Eds.) Methods for research on soilborne phytopathogenic fungi. St. Paul MN. APS Press. 1992. pp. 157-165.

DOMSCH, K.H., GAMS, W. \& ANDERSON, T.H. Compendium of soil fungi. Vol. 1. London. Academic Press. 1980.

GAMLIEL, A. \& STAPLETON, J.J. Characterization of antifungal volatile compounds evolved from solarized soil amended with cabbage residues. Phytopathology 83:899-905. 1993.

GUPTA, S., ARORA, D.K. \& SRIVASTAVA, A.K. Growth promotion of tomato plants by rhizobacteria and imposition of energy stress on Rhizoctonia solani. Soil Biology Biochemistry 27:1051-1058. 1995.

KATARIA, H.R. \& GROVER, R.K. Influence of soil factors, fertilizers and manures on pathogenicity of Rhizoctonia solani on Vigna species. Plant and Soil 103:57-66. 1987.

KLOEPPER, J.W., RODRÍGUEZ-KÁBANA, R., MCINROY, J.A. \& YOUNG, R.W. Rhizosphere bacteria antagonistic to soybean cyst (Heterodera glycines) and root-knot (Meloidogyne incognita) nematodes: identification by fatty acid analysis and frequency of biological control activity. Plant and Soil 139:75-84. 1992.

KOKALIS-BURELLE， N. \& RODRÍGUEZ-KÁBANA， R. Changes in populations of soil microorganisms, nematodes, and enzyme activity associated with application of powdered pine bark. Plant and Soil 162:169-175. 1994a.

KOKALIS-BURELLE, N. \& RODRÍGUEZ-KÁBANA, R. Effects of pine bark extracts and pine bark powder on fungal pathogens, soil enzyme activity, and microbial populations. Biological Control 4:269-276. 1994b.

KOUSIK, C.S., SNOW, J.P., BERGGREN, G.T. \& HARVILLE, B.G. Effect of temperature on virulence of Rhizoctonia solani on soybean leaves and seedlings. Plant Pathology 44:580-586. 1995.

LEWIS, J.A. \& PAPAVIZAS, G.C. Reduction of inoculum of Rhizoctonia solani in soil by germilings of Trichoderma hamatum. 
Soil Biology Biochemistry 19:195-201. 1987.

LINDERMAN, R.G. Organic amendments and soil-borne diseases. Canadian Journal of Plant Pathology 11:180-183. 1989.

McGEE, D.C. Soybean diseases: a reference source for seed technologists. St. Paul MN. APS Press. 1992.

NAIKI, T. \& UI, T. Ultrastructure of sclerotia of Rhizoctonia solani Kühn invaded and decayed by soil microorganisms. Soil Biology Biochemistry 7:301-304. 1975.

OGLE, H.J., STIRLING, A.M. \& DART, P.J. Some factors affecting the development and biocontrol of cotton seedling disease. Australian Journal of Experimental Agriculture 35:771-776. 1995.

RIZVI, S.S.A. \& YANG, X.B. Fungi associated with soybean seedling disease in Iowa. Plant Disease 80:57-60. 1996.

RODRÍGUEZ-KÁBANA, R., BACKMAN, P.A. \& WILLIAMS, J.C. A soil plate method for rapid screening of pesticides against Sclerotium rolfsii. Plant Disease Reporter 59:439-442. 1975.

RODRÍGUEZ-KÁBANA, R., PINOCHET, J., ROBERTSON, D.G. \& WELLS, L. Crop rotation studies with velvetbean (Mucuna deeringiana) for the management of Meloidogyne spp. Journal of Nematology 24(Suppl.):662-668. 1992.

SCHNÜRER, J. \& ROSSWAL, T. Fluorescein diacetate hydrolysis as a measure of total microbial activity in soil and litter. Applied Environmental Microbiology 43:1256-1261. 1982.

SOLER-SERRATOSA, A., KOKALIS-BURELLE, N., RODRÍGUEZ-KÁBANA, R., WEAVER, C.F. \& KING, P.S. Allelochemicals for control of plant-parasitic nematodes. Nematropica 26:57-71. 1996.

TACHIBANA, H., JOWETT, D. \& FEHR, W.R. Determination of losses in soybean caused by Rhizoctonia solani. Phytopathology 61:1444-1446. 1971.

VERMA, P.R. Biology and control of Rhizoctonia solani on rapeseed: A review. Phytoprotection 77:99-111. 1996.

VOLAND, R.P. \& EPSTEIN, A.H. Development of suppressiveness to diseases caused by Rhizoctonia solani in soils amended with composted and non-composted manure. Plant Disease 78:461-466. 1994.

WILSON, C.L., FRANKLIN, J.D. \& OTTO, B.E. Fruit volatiles inhibitory to Monilinia fructicola and Botrytis cinerea. Plant Disease 71:316-319. 1987.

WINDELS, C.E., KUZNIA, R.A. \& CALL, J. Characterization and pathogenicity of Thanatephorus cucumeris from sugarbeet in Minnesota. Plant Disease 81:245-249. 1997. 